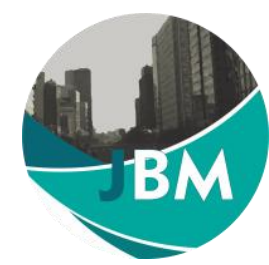

\title{
STUDI SHARED LEADERSHIP DAN PERANNYA DALAM MENINGKATKAN KINERJA KARYAWAN
}

Submitted Date :

20 Maret 2020

Accepted Date :

3 November 2020
Fitri Wulandari

Institut Agama Islam Negeri (lain) Surakarta

fitri.wulandari@iain-surakarta.ac.id

Oktaviyana Ayu Putriyanti

Institut Agama Islam Negeri (lain) Surakarta

oktaviyanaayu@gmail.com

\section{Suggested citation:}

Wu, C., \& Chen, T. (2018). Collective psychological capital: Linking shared leadership, organizational commitment, and creativity. International Journal of Hospitality Management, 74 (May 2017), 75-84. https://doi.org/10.1016/j.jijm.2018.02.003

Abstract:

This paper aims to analyze the effect of shared leadership on employee performance with organizational commitment and employee creativity as a mediating variable. This study used a population of all employees of PT. Pos Indonesia Solo area, with a total sample of 130 respondents. The sampling technique used cluster random sampling. Data were analyzed using path analysis with SPSS version 23. The result showed that shared leadership had a significant and positive effect on employee performance, organizational commitment and employee creativity. Organizational commitment and work creativity also showed as a good antecedent in improving employee performance. The findings of this study illustrate that shared leadership as a contemporary leadership model still receives attention in future research, being able to provide an important influence in increasing organizational commitment and work creativity and improve employee performance.

Keywords: Employee Creativity; Employee Performance, Organizational Commitment, Shared Leadership.

\section{Abstrak:}

Paper ini bertujuan menganalisis pengaruh shared leadership terhadap kinerja karyawan dengan komitmen organisasional dan kreativitas karyawan sebagai variable mediasi. Penelitian ini menggunakan populasi seluruh karyawan PT. Pos Indonesia area Solo, dengan jumlah sampel sebanyak 130 responden. Adapun teknik pengambilan sampel menggunakan cluster random sampling. Data dianalsiis menggunakan analisis jalur dengan aplikasi SPSS versi 23. Hasil penelitian menunjukkan bahwa shared leadership berpengaruh positif signifikan terhadap kinerja karyawan, komitmen organisasi dan juga kreatifitas karyawan. Komitmen organisasional dan kreativitas kerja juga menunjukkan sebagai anteseden yang baik dalam meningkatkan kinerja karyawan. Hasil penelitian ini berhasil membuktikan bahwa komitmen organisasional dan kreativitas karyawan mampu memediasi pengaruh shared leadership terhadap kinerja karyawan. Temuan penelitian ini memberikan gambaran bahwa shared leadership sebagai model kepemimpinan kontemporer masih mendapat perhatian dalam penelitian kedepan, mampu memberikan pengaruh penting dalam meningkatkan komitmen organisasional dan kreativitas kerja dan mendorong kinerja karyawan.

Kata Kunci: Shared Leadership; Komitmen Organisasional; Kreativitas Karyawan; Kinerja Karyawan.

\section{JEL Classification: M12}




\section{Latar Belakang}

Kepemimpinan merupakan cara bagaimana seseorang mempengaruhi dan mengelola orang lain untuk melakukan sesuatu dalam sebuah organisasi. Terdapat beragam gaya kepemimpinan yang salah satunya adalah share leadership. Shared leadership adalah situasi di mana anggota tim terlibat dalam kepemimpinan dan ditandai dengan adanya kolaborasi dalam hal pengambilan keputusan dan tanggung jawab bersama untuk mencapai tujuan (Hoch, 2013). Shared leadership dapat menghasilkan efektivitas yang lebih besar daripada pemimpin tunggal dalam tim internal (Carson et al., 2007). Dan juga Shared leadership cenderung lebih efektif pada anggota tim yang memiliki kompetensi tugas tinggi, tugas relatif kompleks, dan tingkat ketergantungan yang tinggi.

Shared leadership dianggap sebagai properti tim dimana pemimpin mencoba mendistribusikan kewenangan yang dimilikinya kepada kelompok atau tim kerja (C. Wu \& Chen, 2018). Sehingga menurut Hoch (2013) bahwa shared leadership merupakan perpaduan dari kepemimpinan transformasional, pemberdayaan karyawan, dan juga pemimpin yang memiliki integritas. Diperkuat oleh Carson et al., (2007) bahwa shared leadership merupakan fenomena relasional yang melibatkan pengaruh timbal balik antara anggota tim dengan kelompok (Sung et al., 2014).

Riset gap dalam penelitian ini adalah pengaruh shared leadership dalam mendorong kinerja karyawan, seperti yang disajikan dalam penelitian (Carson et al., 2007; Han et al., 2018; Mohd Adnan \& Valliappan, 2019; Afif George Nassif, 2019). Hasil penelitian dilakukan D'Innocenzo \& Mathieu (2016) mengatakan bahwa kompleksitas tugas tim mampu memediasi pengaruh shared leadership terhadap kinerja karyawan, namun pada tugas yang semakin kompleks dan ukuran tim yang semakin besar maka pengaruh tersebut juga semakin melemah. Selanjutnya Carson et al. (2007) mengatakankan bahwa shared leadership adalah prediktor kuat dan positif dari kinerja karyawan. Didukung oleh penelitian Nassif (2018) yang mengemukakan terdapat pengaruh positif shared leadership terhadap kinerja karyawan. Namun demikian proses seperti apa yang menyebabkan shared leadership akan meningkatkan kinerja masih terdapat ketidakjelasan dan menyisakan berbagai pertanyaan dan alasan mengapa shared leadership dapat meningkatkan kinerja karyawan.

Dalam penelitian sebelumnya (Sung et al., 2014; C. Wu \& Chen, 2018) menjelaskan bahwa keselarasan tujuan antar anggota dengan tujuan kolektif tim, dukungan sosial anggota tim terhadap tim untuk saling bekerja secara bahu membahu, serta kontribusi anggota tim dengan keterlibatannya dalam pengambilan keputusan akan meningkatkan komitmen organisasional, mendorong kreativitas karyawan yang pada akhirnya akan meningkatkan kinerja karyawan. Komitmen organisasional adalah konsep mengenai pola pikir, atau keadaan psikologis seseorang terkait dengan perasaan dan kepercayaan karyawan dengan organisasi (Meyer \& Allen, 1991). Keterikatan yang kuat terhadap organisasi akan meningkatkan kontribusi karyawan terhadap organisasi. Fokus penelitian ini adalah peran shared leadership dalam meningkatkan komitmen organisasional dan kreativitas karyawan dan dampaknya terhadap kinerja karyawan. Shared leadership diharapkan akan meningkatkan kreativitas kerja, karena shared leadership menekankan interaksi harmonis yang mendorong kreatif dan meningkatkan inovasi. Kreativitas merupakan inisiatif untuk berproses dalam memproduksi ide yang bermanfaat dan tepat serta ide-ide orisinil yang memberikan pengaruh pada perubahan organisasi kearah yang lebih baik (C. Wu \& Chen, 2018).

\section{Kajian Literatur}

\section{Shared Leadership}

Shared leadership merupakan tipe kepemimpinan, dimana pemimpin cenderung mendistribusikan berbagai wewenang, kekuasaan dan tanggung jawab kepada anggota secara individu dan juga kelompok atau tim (Afif George Nassif, 2019). Pandangan ini diperkuat oleh Q. Wu \& Cormican (2016) yang mengatakan bahwa shared leadership merupakan pengaruh secara luas yang timbul dari distribusi tanggung jawab kepemimpinan di antara anggota tim. Shared leadership memberikan dasar bagi anggota tim untuk memahami dimana dan kapan mereka dapat menyumbangkan pengetahuan kepada anggota tim lainnya, sehingga meningkatkan kemampuan tim untuk memberikan pengetahuan berkualitas tinggi (Muethel \& Hoegl, 2016).

Carson et al, (2007) menyatakan bahwa shared leadership terdiri dari pertama, shared purpose merupakan kondisi ketika anggota tim memiliki pemahaman yang sama terhadap tujuan utama tim dan memastikan bahwa langkah-langkah yang dilakukan berfokus pada tujuan kolektif. Ketika suatu tim memiliki shared purpose, maka akan dapat meningkatkan kesediaan anggota tim untuk berbagi tanggung jawab kepemimpinan. Kedua, social support merupakan usaha yang saling dilakukan anggota tim untuk memberikan kekuatan secara emosional dan psikologis. 


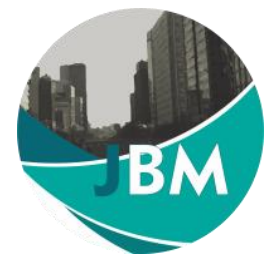

Hal ini dilakukan anggota tim yang saling mendukung dengan cara memberi dorongan dan mengakui kontribusi serta pencapaian individu maupun tim. Social support dapat membantu menciptakan lingkungan di mana anggota tim merasa bahwa gagasan mereka dihargai. Ketiga adalah voice didefinisikan sebagai kondisi mengenai sejauh mana anggota tim memiliki gagasan tentang bagaimana tim menjalankan sesuatu agar tujuan tercapai.

Shared leadership sebagai kualitas dan proses dalam tim yang membuat suatu mekanisme untuk menyatukan aggota tim serta memperkuat komitmen untuk kesuksesan tim (A George Nassif, 2018). Menurut C. Wu \& Chen (2018) yang menyatakan bahwa shared leaderhip memiliki implikasi terhadap kinerja karyawan. Dengan adanya pemahaman yang sama terhadap tujuan utama tim, adanya dorongan secara emosional dan psikologis, serta adanya keterlibatan angota tim untuk berkolaborasi dalam hal pengambilan keputusan dan tanggung jawab maka karyawan akan berkinerja lebih baik dalam organisasi.

\section{Komitmen organisasional}

Komitmen organisasional merupakan keterikatan emosional yang kuat dari karyawan untuk berkontribusi kepada organisasi. Komitmen organisasional terbentuk karena karyawan dalam organisasi memiliki kesamaan visi, kesamaan misi dan tujuan serta memiliki kesamaan nilai dengan organisasi. Komitmen Organisasional cenderung meningkat jika anggota kelompok dapat merasakan visi bersama dan dukungan dari para pemimpin bersama (Wu \& Chen, 2018). Meyer \& Allen (1991) dan Aydoğan \& Arslan, (2020) menjabarkan tiga komitmen yaitu komitmen afektif, komitmen normative dan komitmen berkelanjutan.

Komitmen afektif didefiniskan sebagai keyakinan kuat terhadap organisasi, memiliki kesamaan tujuan dan juga nilai-nilai dengan organisasi, kemauan untuk melakukan sejumlah besar upaya atas nama organisasi, dan hasrat yang kuat untuk mempertahankan keanggotaan dalam organisasi (Mayer et al., 1995; Noorman et al., 2015). Karyawan yang memiliki komitmen afektif tinggi akan cenderung bekerja dengan organisasi atas dasar keinginan dari dalam dirinya sendiri. Kedua adalah komitmen normative yang mencerminkan perasaan karyawan bahwa ia memiliki kewajiban untuk melajutkan pekerjaan. Komitmen normatif merupakan keterikatan perasaan seseorang terhadap organisasi untuk tetap berada dalam organisasi tersebut karena berhubungan dengan masalah etika (Mohamed \& Anisa, 2012). Ketiga adalah komitmen berkelanjutan, mengacu pada pemikiran mengenai biaya jika meninggalkan organisasi. Karyawan dengan komitmen berkelanjutan tinggi akan mengambil keputusan untuk memilih menetap dalam organisasi karena pertimbangan biaya jika meninggalkan organisasi (Mohamed \& Anisa, 2012). Penelitian C. Wu \& Chen (2018) menunjukkan bahwa shared leadership positif dan signifikan berpengaruh dengan komitmen organisasional. Dalam penelitiannya menyatakan bahwa shared leadership merupakan rumusan dari budaya berbagi dan dukungan dalam struktur sosial yang mendorong komitmen organisasional dan kinerja karyawan.

\section{Kreativitas karyawan}

Kreativitas pada tingkat individu berhubungan dengan situasi dimana seseorang memiliki kemampuan memecahkan masalah dalam pekerjaan, memikirkan cara-cara yang paling mudah dalam menyelesaikan pekerjaan atau menemukan ide baru yang belum pernah dilakukan. Kreativitas sangat diperlukan untuk mendukung suatu pekerjaan atau tugas tertentu. Sejalan dengan pandangan Shang, Chong, Xu, \& Zhu (2019) dewasa ini kreativitas menjadi isu penting dalam setiap kegiatan bisnis karena kreativitas identitik dengan ketrampilan yang unggul dan ide-ide baru yang berkontribusi pada organisasi. Diperkuat oleh Shafi, Zoya, Lei, Song, \& Sarker (2020) bahwa kreativitas karyawan merupakan pemikiran karyawan yang diwujudkan dengan berbagi ide-ide baru yang original dan berguna untuk organisasi.

Pada dasarnya pemimpin harusnya mendorong agar karyawan lebih kreatif dalam pekerjaannya. Semakin karyawan memiliki pengalam kerja yang beragam, ketrampilan dan keahlian yang terus berkembang maka kreativitas cenderung meningkat. Ketika pemimpin menghargai dan menghormati ide-ide karyawan, maka mereka akan cenderung untuk lebih menghasilkan ide-ide baru (C. Wu \& Chen, 2018). Selain itu, adanya dukungan yang baik antara anggota kelompok, komunikasi yang baik, dan juga koordinasi yang berjalan baik, maka anggota kelompok cenderung untuk berbagi pengetahuan dan menyumbangkan ide-ide unik dan inovatif kepada anggota kelompok lainnya. Penelitian C. Wu \& Chen (2018) menemukan bahwa shared leadership positif dan signifikan berpengaruh dengan 
kreativitas, melalui meningkatnya kualitas layanan dengan adanya ide-ide kreatif. Penelitian Q. Wu \& Cormican (2016) juga mendukung pandangan adanya pengaruh positif kepemimpinan terhadap kreativitas karyawan.

\section{Kinerja karyawan}

Pandangan (Campbell et al., 1990, 1993) menjelaskan bahwa ketika mengkonseptualisasikan kinerja harus membedakan keduanya sebagai aspek tindakan (yaitu, perilaku) dan aspek hasil kinerja (Borman \& Motowidlo, 1997; Garud \& Nayyar, 1994). Perilaku mengacu pada aspek apa yang dilakukan seseorang dalam situasi kerja. Setiap perilaku yang dimasukkan sebagai konsep kinerja, hanya pada perilaku yang ada relevansinya dengan tujuan organisasi. Sedangkan aspek hasil mengacu pada konsekuensi atau akibat dari perilaku individu. Pandangan Lee et al., (2010) dan (Lee et al., 2010; Quigley et al., 2007) bahwa kinerja dapat diukur dengan dua dimensi yaitu kinerja tugas (atau prestasi kerja) yaitu perilaku yang terkait dengan pelayanan inti teknis organisasi dan kinerja kontekstual mengacu pada berbagai aktivitas yang tidak terkait dengan inti tehnis namun mendukung kinerja organisasi dalam jangka panjang. Ketika mengkonseptualisasikan kinerja seseorang harus membedakan antara tindakan (yaitu, perilaku) dan aspek hasil kinerja (Bebchuk \& Roe 1999). Aspek perilaku mengacu pada apa yang dilakukan seseorang dalam situasi kerja yang mencakup perilaku yang relevan untuk tujuan organisasi. Aspek hasil mengacu pada konsekuensi atau hasil dari perilaku individu. Kinerja didefinisikan sebagai tingkat dimana seseorang mengeksekusi perannya dengan mengacu pada standar yang ditetapkan oleh organisasi.

Pandangan lain mengenai kinerja dalam perusahaan jasa atau kinerja layanan selalu berfokus pada bagaimana kinerja layanan yang berfokus pada tingkat organisasi maupun individu. Namun, sebagian besar dari pengukuran kinerja menangani tingkat organisasi, dan beberapa peneliti memusatkan perhatian pada kinerja layanan di tingkat individu (Acar \& Zehir, 2013). Pentingnya pemahaman memperhatikan kinerja individu pada saat ini karena sebagian besar perusahaan di industri jasa menyadari bahwa perilaku berorientasi pelanggan lebih menekankan orientasi personal individu dalam memberikan pelayanan garda depan.

\section{Metode Penelitian}

\section{Populasi dan Sampel}

Populasi penelitian ini adalah seluruh karyawan PT. Pos Indonesia area Solo. Penarikan sampel dilakukan seperti pada kebanyakan kasus, bahwa tidak memungkinkan seorang penelitian meneliti seluruh anggota populasi. Oleh karena itu, peneliti memilih sebuah perwakilan dari populasi yang disebut dengan sampel. Penelitian ini menggunkaan cluster random sampling sebagai metode pengambilan sampel. Sampel dalam penelitian meliputi karyawan PT POS di kantor cabang Solo dan juga pegawai dikantor unit Semanggi, Jebres, UNS, Mojosongo, Setabelan, Nusukan, Cengklik, Sriwedari, Kerten, Jajar, Pasar Jongke, Purwosari, Tipes, Gading, makam Haji, UMS dan Solobaru. Jumlah kuesioner yang didistribusikan kepada responden dalam penelitian ini sebanyak 170 kuesioner dan jumlah yang kembali dan layak untuk dilakukan analisis data adalah 130 responden.

\section{Pengukuran}

Shared Leadership diukur dengan keterlibat kepemimpinan dan ditandai dengan adanya kolaborasi dalam hal pengambilan keputusan dan tanggung jawab bersama untuk mencapai tujuan (Hoch, 2013; A George Nassif, 2018). Komitmen organisasional diukur dengan komitmen afektif, komitmen normative dan komitmen berkelanjutan (Meyer \& Allen, 1991). Kreativitas karyawan diukur dengan menyarankan ide-ide baru, cara baru yang berbeda dari sebelumnya, mampu menunjukkan kreativitas pekerjaan ketika mendapat kesempatan (Shafi et al., 2020; Q. Wu \& Cormican, 2016). Kinerja karyawan diukur dari kualitas kerja, kuantitas kerja, efektivitas kerja, pekerjaan yang sejalan dengan standar organisasi (Borman \& Motowidlo, 1997; Garud \& Nayyar, 1994). 
Hasil Penelitian

\section{Deskripsi Karakteristik Responden}

Tabel 1. Hasil uji tabulasi silang pengalaman kerja dan pendidikan Experience * Education Crosstabulation

\begin{tabular}{|lll|r|r|r|r|}
\hline & & \multicolumn{2}{c|}{ Education } & \multirow{2}{*}{ Total } \\
\cline { 3 - 6 } & & $\begin{array}{c}\text { Senior High } \\
\text { School }\end{array}$ & Diploma & Bachelor/Magister & \\
\hline Experience & $1-5$ years old & Count & 13 & 8 & 7 & 28 \\
& \% of Total & $10,0 \%$ & $6,2 \%$ & $5,4 \%$ & $21,5 \%$ \\
\cline { 2 - 6 } & $6-10$ years old & Count & 28 & 13 & 15 & 56 \\
& \% of Total & $21,5 \%$ & $10,0 \%$ & $11,5 \%$ & $43,1 \%$ \\
\cline { 2 - 6 } & $11-15$ years old & Count & 33 & 6 & 7 & 46 \\
& \% of Total & $25,4 \%$ & $4,6 \%$ & $5,4 \%$ & $35,4 \%$ \\
\hline Total & Count & 74 & 27 & 29 & 130 \\
& & \% of Total & $56,9 \%$ & $20,8 \%$ & $22,3 \%$ & $100,0 \%$ \\
\hline
\end{tabular}

Berdasarkan Tabel 1 responden penelitian ini adalah mereka yang memiliki pengalaman antara 1 tahun hingga 15 tahun, dengan pendidikan SMU, D3 atau S1/S2. Pengalaman terbanyak responden adalah antara 6 sampai 10 tahun dengan prosentase $43,1 \%$ dan pendidikan terbanyak adalah lulusan SMU. Berdasarkan data di atas juga dapat disimpulkan bahwa secara umum para responden didominasi oleh mereka yang memiliki masa kerja 6 sampai 10 tahun dengan pendidikan SMU. Artinya kebijakan perusahaan dalam perekrutan tidak mengutamakan pendidikan, tetapi lebih pada kemampuan karyawan untuk bekerja sesuai dengan bidang pekerjaan.

Tabel 2. Hasil uji tabulasi silang usia dan jabatan responden

Age * Position Crosstabulation

\begin{tabular}{|lll|r|r|r|r|r|r|}
\hline & & \multicolumn{4}{|c|}{ Position } & \multirow{2}{*}{ Total } \\
\cline { 3 - 7 } & & Staff & Organizer & Fungtional & Manager & Head Office & \\
\hline Age & $21-30$ & Count & 41 & 2 & 1 & 0 & 0 & 44 \\
& & $\%$ of Total & $31,5 \%$ & $1,5 \%$ & $0,8 \%$ & $0,0 \%$ & $0,0 \%$ & $33,8 \%$ \\
\cline { 2 - 7 } & $31-40$ & Count & 37 & 0 & 4 & 2 & 1 & 44 \\
& \% of Total & $28,5 \%$ & $0,0 \%$ & $3,1 \%$ & $1,5 \%$ & $0,8 \%$ & $33,8 \%$ \\
\cline { 2 - 7 } & $40-50$ & Count & 31 & 2 & 1 & 4 & 4 & 42 \\
& \% of Total & $23.8 \%$ & $1.5 \%$ & $0.8 \%$ & $3.1 \%$ & $3.1 \%$ & $32.3 \%$ \\
\hline Total & & Count & 109 & 4 & 6 & 6 & 5 & 130 \\
& & $\%$ of Total & $83.8 \%$ & $3.1 \%$ & $4.6 \%$ & $4.6 \%$ & $3.8 \%$ & $100.0 \%$ \\
\hline
\end{tabular}

Berdasarkan Tabel 2 responden dalam penelitian ini adalah mereka yang berusia antara 21 tahun hingga 50 tahun, dengan jabatan sebagai staf, pelaksana, fungsional, manager dan kepala kantor. Responden terbanyak adalah mereka yang berusia antara 21 - 40 tahun sebanyak $67,7 \%$ sedang yang berusia antara 40 - 50 tahun adalah 32,3\% responden. Sebagian besar responden adalah staf sebagai pelaksana tehnis dengan jumlah mencapai $83,8 \%$, sisanya adalah para pelaksana, manajer, fungsional dan kepala unit. Berdasarkan data di atas juga dapat disimpulkan bahwa secara umum para responden didominasi oleh mereka yang berusia dari 30 tahun untuk jabatan pelaksana, manajer, fungsional dan kepala unit. Jabatan yang telah mereka raih diikuti dengan pengalaman kerja yang relatif lama, sehingga mereka menduduki posisi strategis di organisasi pada saat usia semakin matang. 


\section{Uji Validitas}

Uji validitas dapat dilihat pada tabel 3 dilakukan untuk menguji ketepatan alat pengukur apakah akurasi untuk menjelaskan konsep yang diukur. Pengujian validitas tersaji dalam tabel berikut:

Tabel 3 Hasil Uji Validitas

\begin{tabular}{|c|c|c|c|c|}
\hline Variabel & Item & $\mathbf{r}$ hitung & $\mathbf{r}$ tabel & Keterangan \\
\hline \multirow{4}{*}{ Shared Leadership } & SL1 & 0,816 & 0,1723 & Akurat \\
\cline { 2 - 5 } & SL2 & 0,903 & 0,1723 & Akurat \\
\cline { 2 - 5 } & SL3 & 0,914 & 0,1723 & Akurat \\
\cline { 2 - 5 } & SL4 & 0,912 & 0,1723 & Akurat \\
\cline { 2 - 5 } & SL5 & 0,913 & 0,1723 & Akurat \\
\hline \multirow{5}{*}{ Krganisasional } & KO1 & 0,891 & 0,1723 & Akurat \\
\cline { 2 - 5 } & KO2 & 0,879 & 0,1723 & Akurat \\
\cline { 2 - 5 } & KO3 & 0,894 & 0,1723 & Akurat \\
\cline { 2 - 5 } & KO4 & 0,870 & 0,1723 & Akurat \\
\cline { 2 - 5 } & KO5 & 0,825 & 0,1723 & Akurat \\
\cline { 2 - 5 } & KO6 & 0,828 & 0,1723 & Akurat \\
\hline Kreativitas & CK1 & 0,836 & 0,1723 & Akurat \\
\cline { 2 - 5 } & CK2 & 0,910 & 0,1723 & Akurat \\
\cline { 2 - 5 } & CK3 & 0,869 & 0,1723 & Akurat \\
\cline { 2 - 5 } & CK4 & 0,866 & 0,1723 & Akurat \\
\hline \multirow{5}{*}{ Kinerja Karyawan } & KK1 & 0,775 & 0,1723 & Akurat \\
\cline { 2 - 5 } & KK2 & 0,896 & 0,1723 & Akurat \\
\cline { 2 - 5 } & KK3 & 0,888 & 0,1723 & Akurat \\
\cline { 2 - 5 } & KK4 & 0,894 & 0,1723 & Akurat \\
\cline { 2 - 5 } & KK5 & 0,871 & 0,1723 & Akurat \\
\hline
\end{tabular}

\section{Uji Reliabilitas}

Uji reliabilitas dapat dilihat pada tabel 4 dilakukan untuk memastikan kuesioner pada penelitian ini reliabel atau tidak. Pengujian dilakukan menggunakan uji statistic croncbach alpha (a), dimana variabel dikatakan reliabel jika nilai pada croncbach alpha> 0,70.

Tabel 4. Hasil Uji Reliabilitas

\begin{tabular}{|l|c|l|}
\hline \multicolumn{1}{|c|}{ Variabel } & Chonbach Alpha & Keterangan \\
\hline Shared Leadership & 0,935 & Konsisten \\
\hline Komitmen Organisasional & 0,931 & Konsisten \\
\hline Kreativitas karyawan & 0,893 & Konsisten \\
\hline Kinerja karyawan & 0,916 & Konsisten \\
\hline
\end{tabular}

\section{Uji Normalitas}

Uji normalitas dilakukan untuk mengetahui sebaran data pada penelitian apakah berdistribusi normal atau tidak. Pengujian dilakukan dengan menggunakan uji Kolmogorov-Smirnov (K-S). Berikut merupakan hasil dari pengujian menggunakan uji Kolmogorov-Smirnov (K-S):

Tabel 5. Hasil Uji Normalitas

\begin{tabular}{|c|c|}
\hline Statistics & Unstandardized Residual Value \\
\hline Kolmogorov Smirnov & 0,074 \\
\hline Asymp. Sig. (2-tailed) & 0,075 \\
\hline
\end{tabular}


Nilai dalam tabel.5. terdistribusi normal jika besarnya nilai kolmogorov smirnov lebih besar dari $5 \%$, pada hasil ditunjukkan bahwa nilai dari Asymp. Sig. (2- tailed) $>0,05$ yaitu 0,75>0,05. Sehingga dalam penelitian ini hasilnya data terdistribusi secara normal.

\section{Uji Multikolinieritas}

Uji multikolinieritas digunakan untuk menguji model regresi apakah ditemukan korelasi antar variabel independan. Model regresi yang tidak terjadi korelasi antara variabel independen adalah model regresi yang baik.

Tabel 6. Hasil Uji Multikolinieritas

\begin{tabular}{|l|c|c|c|}
\hline \multicolumn{1}{|c|}{ Variabel } & Tolerance & VIF & Keterangan \\
\hline Shared Leadership & 0,397 & 2,520 & Tidak terdapat multikolinearitas \\
\hline Organizational Commitment & 0,298 & 3,351 & Tidak terdapat multikolinearitas \\
\hline Kreativitas karyawan & 0,437 & 2,289 & Tidak terdapat multikolinearitas \\
\hline
\end{tabular}

Hasil dalam table.6. menunjukkan bahwa nilai tolerance $\geq 0,10$ dan juga nilai $\mathrm{VIF} \leq 10$, maka model regresi yang digunakan pada penelitian ini tidak terdapat korelasi antar variabel independennya. Hasil dalam tabel. 7. menunjukkan bahwa berdasarkan pada hasil uji parsial atau (uji t) terbukti semuanya berpengaruh signifikan positif.

Tabel 7. Hasil pengujian Regresi dengan SPSS versi 23.

\begin{tabular}{|l|l|l|l|l|l|l|}
\hline Pengaruh variable & Estimate & SE & t-value & $\rho$-value & F & Explanation \\
\hline Shared Leadership $\rightarrow$ Kinerja Karyawan & 0,175 & 0,065 & 2,703 & 0,008 & 83,589 & Accepted \\
\hline $\begin{array}{l}\text { Shared Leadership } \rightarrow \text { Komitmen } \\
\text { Organisasional }\end{array}$ & 0,932 & 0,068 & 13,688 & 0,000 & 187,363 & Accepted \\
\hline $\begin{array}{l}\text { Shared Leadership } \rightarrow \text { Kreativitas } \\
\text { Karyawan }\end{array}$ & 0,409 & 0,044 & 9,348 & 0,000 & 87,384 & Accepted \\
\hline $\begin{array}{l}\text { Komitmen Organisasional } \rightarrow \text { Kinerja } \\
\text { karyawan }\end{array}$ & 0,177 & 0,062 & 2,867 & 0,005 & 83,589 & Accepted \\
\hline $\begin{array}{l}\text { Kreativitas Karyawan } \rightarrow \text { Kinerja } \\
\text { Karyawan }\end{array}$ & 0,508 & 0,096 & 5,287 & 0,000 & 83,589 & Accepted \\
\hline
\end{tabular}

Uji Mediasi Variabel Shared Leadership, Komitmen Organisasional dan Kinerja Karyawan.

Untuk mengetahui peran mediasi dari variable komitmen organisasional sebagai variabel intervening dari shared leadership dengan kinerja karyawan dapat disajikan dalam hasil uji sobel. Dalam hasil dengan sobel test ditunjukkan dengan nilai sebesar 2.79485373 dengan nilai P-Value yang diuji pada two-tailed probability (pengujian dua sisi) sama dengan 0.00519232 , nilai dibawah nilai signifikansi 5 persen. Sehingga hasil menunjukkan bahwa variabel komitmen organisasional mampu memediasi pengaruh shared leadership terhadap kinerja karyawan.

\section{Uji Mediasi Variabel Shared Leadership, Kreativitas Karyawan dan Kinerja Karyawan.}

Untuk mengetahui peran mediasi dari variable kreativitas sebagai variabel intervening dari shared leadership dengan kinerja karyawan dapat disajikan dalam hasil uji sobel. Dalam hasil dengan sobel test ditunjukkan dengan nilai sebesar 4.59871410 dengan nilai P-Value yang diuji pada two-tailed probability (pengujian dua sisi) sama dengan 0.00000425 , nilai dibawah nilai signifikansi 5 persen. Sehingga hasil menunjukkan bahwa variabel kreativitas karyawan mampu memediasi pengaruh shared leadership terhadap kinerja karyawan.

\section{Pembahasan}

\section{Pengaruh Shared Leadership terhadap Kinerja Karyawan.}

Shared leadership berpengaruh positif signifikan terhadap kinerja karyawan. Shared leadership adalah kepemimpinan dalam kelompok atau tim yang ditandai dengan distribusi wewenang dan tanggung jawab. Kompleksitas tugas yang 
tinggi menuntut karyawan memiliki tim kerja yang baik dan tipe kepemimpinan yang efektif, sehingga karyawan mampu menyelesaikan pekerjaan dan mencapai target yang telah ditetapkan organisasi (Müller et al., 2018). Studi menunjukkan bahwa shared leadership menyebabkan pekerjaan lebih terdesentralisasi, yang berdampak pada hubungan yang lebih erat antara pemimpin dan anggota tim, yang mendorong interaksi untuk saling berbagi ilmu, kemampuan dan keterampilan, menurunkan tingkat kesalahan tim dan meningkatkan kualitas kinerja. Shared leadership tidak hanya membantu menyelesaikan target dengan cepat, namun juga sebuah pekerjaan yang berkualitas (Han et al., 2018).

Pengaruh Shared Leadership terhadap Komitmen Organisasional, pengaruh Komitmen Organisasional terhadap Kinerja Karyawan serta pengaruh Shared Leadership terhadap Kinerja Karyawan dengan mediasi Komitmen Organisasional.

Hasil mendukung temuan penelitian sebelumnya bahwa shared leadership berpengaruh positif signifikan terhadap komitmen organisasional. Shared leadership merupakan kepemimpinan dengan pengaruh timbal balik antara anggota tim dan adanya kolaborasi dalam hal pengambilan keputusan, meningkatkan keterikatan kuat terhadap organisasi dan keinginan yang kuat untuk tetap tinggal di organisasi (Han et al., 2018). Sejalan dengan temuan C. Wu \& Chen, (2018) yang menyatakan bahwa shared leadership merupakan anteseden dalam meningkatkan komitmen organisasional. Penelitian C. Wu \& Chen (2018) menunjukkan bahwa shared leadership signifikan positif berpengaruh terhadap komitmen organisasional. Shared leadership akan meningkatkan kerjasama dan koordinasi tim, memperluas keinginan berbagi pengetahuan dalam tim, meningkatkan komitmen karyawan dan pada akhirnya akan berdampak positif terhadap kinerja tim.

Bahwa shared leadership melalui mediasi komitmen organisasional mempunyai pengaruh signifikan terhadap kinerja karyawan PT. Pos Indonesia. Komitmen organisasional dapat meningkat jika ada keterikatan antara karyawan dengan organisasi. Keterikatan tersebut dapat timbul ketika shared leadership diterapkan dalam kepemimpinan. Jika komitmen organisasional tinggi maka kinerja karyawan juga akan tinggi. Hasil penelitian ini mendukung pernyataan dalam penelitian yang dilakukan oleh C. Wu \& Chen (2018) menunjukkan bahwa shared leadership positif dan signifikan berpengaruh terhadap komitmen organisasional. Shared leadership akan mendorong perilaku berbagi yang tinggi, budaya saling mendukung, iklim kerja yang kondusif dan responsive, meningkatnya kepercayaan antar tim kerja yang pada akhirnya tidak hanya meningkatkan komitmen organisasional namun juga memberikan dampak pada peningkatan kinerja karyawan secara signifikan.

\section{Pengaruh Shared Leadership terhadap Kreativitas Karyawan, pengaruh Kreativitas Karyawan terhadap Kinerja Karyawan serta pengaruh Shared leadership terhadap Kinerja Karyawan dengan mediasi Kreativitas Karyawan.}

Hasil analisis dari penelitian ini menunjukkan bahwa shared leadership berpengaruh positif signifikan terhadap kreativitas karyawan. Shared leadership akan meningkatkan kreativitas karyawan, karena tipe kepimpinan yang berkolaborasi, mendistribusikan kewenangan dan tanggung jawab akan mendorong karyawan berkreasi terhadap ide baru (Hughes et al., 2018). Kreativitas tim memiliki pengaruh langsung pada kemampuan tim dalam mengeksplorasi dan bertransformasi untuk meningkatkan pengetahuan organisasi (Cavazotte \& Paula, 2020).

Hasil menunjukkan bahwa shared leadership melalui mediasi kreativitas karyawan mempunyai pengaruh signifikan terhadap kinerja karyawan PT. Pos Indonesia area Solo. Kreativitas karyawan merupakan hal yang penting ditingkatkan untuk menunjang kinerja karyawan. Hasil penelitian ini mendukung penelitian sebelumnya oleh $(Q$. Wu \& Cormican, 2016) bahwa shared leadership positif dan signifikan dengan kreativitas karyawan yang berimplikasi pada kinerja karyawan.

\section{Kesimpulan dan Saran}

Strategi terbaik untuk meningkatkan kinerja karyawan dalam penelitian ini adalah peran shared leadership terhadap komitmen organisasional dan berdampak pada kinerja. Sehingga perlu didukung bagaimana dapat meningkatkan shared leadership yang akan menguatkan keterikatan yang kuat antara karyawan dengan organisasi, perasaan bangga menjadi bagian dari organisasi, memiliki keselarasan nilai dengan organisasi yang pada akhirnya akan meningkatkan kinerja karyawan. Berdasarkan hasil penelitian, komitmen organisasional merupakan variabel yang 
Jurnal Bisnis dan Manajemen

http://jurnal.unmer.ac.id/index.php/jbm
Volume 7 No 2

2020

HIm. 74 - 84

paling berdampak dalam meningkatkan kinerja karyawan. Hasil penelitian menunjukkan bahwa kreativitas karyawan dan komitmen organisasional keduanya mampu memediasi pengaruh shared leadership terhadap kinerja karyawan.

Studi ini memberikan implikasi praktis yang penting bagi manajemen, karena berbagai prilaku karyawan di tempat kerja cenderung bergantung pada komitmen organisasional terutama komitmen afektif, dengan menekankan pentingnya mengelola SDM berbasis keterikatan yang kuat antara karyawan dan organisasi yang memiliki kesamaan visi, kesamaan tujuan dan kesamaan nilai. Hubungan emosional yang kuat dengan organisasi menyebabkan kerelaan untuk terus mengembangkan organisasi, bangga menjadi bagian dari organisasi dan terus memikirkan masa depan organisasi.

Penelitian ini hanya menggunakan satu unit analisis organisasi yaitu PT Pos Indonesia wilayah VI dengan obyek PT Pos Surakarta. Kedepan perlu dipertimbangkan melakukan penelitian pada beragam organisasi atau dengan wilayah yang berbeda.

\section{Daftar Pustaka}

Acar, A. Z., \& Zehir, C. (2013). The effects of customer and entrepreneurial orientations on individual service performance in banking sector. Procedia - Social and Behavioral Sciences, 99(1978), 526-535. https://doi.org/10.1016/j.sbspro.2013.10.522

Arvey, R. D., \& Murphy, K. R. (1998). Performance evaluation in work settings. Annual Review of Psychology, 49(1), 141-168.

Aydoğan, E., \& Arslan, Ö. (2020). HRM practices and organizational commitment link: maritime scope. International Journal of Organizational Analysis. https://doi.org/10.1108/IJOA-02-2020-2038

Bebchuk, L. A., \& Roe, M. J. (1999). A theory of path dependence in corporate ownership and governance. Stanford Law Review, 127-170.

Bolatan, G. I. S., Gozlu, S., Alpkan, L., \& Zaim, S. (2016). The impact of technology transfer performance on total quality management and quality performance. Procedia-Social and Behavioral Sciences, 235, 746-755. https://doi.org/10.1016/j.sbspro.2016.11.076

Borman, W. C., \& Motowidlo, S. J. (1997). Task performance and contextual performance: The meaning for personnel selection research. Human Performance, 10(2), 99-109.

Campbell, J. P., McCloy, R. A., Oppler, S. H., \& Sager, C. E. (1993). A theory of performance. Personnel Selection in Organizations, 3570, 35-70.

Campbell, J. P., McHenry, J. J., \& Wise, L. L. (1990). Modeling job performance in a population of jobs. Personnel Psychology, 43(2), 313-575.

Carson, J. B., Tesluk, P. E., \& Marrone, J. A. (2007). Shared Leadership in Teams: An Investigation of Antecendent Conditions and Performance. Academy of Management Journal, 50(5), 1217-1234.

Cavazotte, F. S. C. N., \& Paula, F. de O. (2020). Too much of a good thing: The quadratic effect of shared leadership on creativity and absorptive capacity in R\&D teams. European Journal of Innovation Management, 2019(248665). https://doi.org/10.1108/EJIM-11-2019-0327

D'Innocenzo, L., \& Mathieu, J. E. (2016). A meta-analysis of different forms of shared leadership-team performance relations. Journal of Management, 42(7), 1964-1991. https://doi.org/10.1177/0149206314525205

Garud, R., \& Nayyar, P. R. (1994). Transformative capacity: Continual structuring by intertemporal technology transfer. Strategic Management Journal, 15(5), 365-385.

Han, S. J., Lee, Y., Beyerlein, M., \& Kolb, J. (2018). Shared leadership in teams: The role of coordination, goal commitment, and knowledge sharing on perceived team performance. Team Performance Management, 24(34), 150-168. https://doi.org/10.1108/TPM-11-2016-0050 
Hoch, J. E. (2013). Shared Leadership and Innovation : The Role of Vertical Leadership and Employee Integrity. J Bus Psychol, 159-174. https://doi.org/10.1007/s10869-012-9273-6

Hughes, D. J., Lee, A., Tian, A. W., Newman, A., \& Legood, A. (2018). Leadership, creativity, and innovation: A critical review and practical recommendations. Leadership Quarterly, 29(5), 549-569. https://doi.org/10.1016/j.leaqua.2018.03.001

Lee, O. F., Tan, J. A., \& Javalgi, R. (2010). Goal orientation and organizational commitment: Individual difference predictors of job performance. International Journal of Organizational Analysis, 18(1), 129-150.

Mayer, R. C., Davis, J. H., \& Schoorman, F. D. (1995). An integrative model of organizational trust. Academy of Management Review, 20(3), 709-734.

Meyer, J. P., \& Allen, N. J. (1991). A Three-Component Conceptualzation of Organizational Commitment. Human Resource Management Review, 1(1), 61-89. https://doi.org/ISSN: 1053-4822

Mohamed, M. S., \& Anisa, H. (2012). Relationship between organizational commitment and organizational citizenship behavior. The IUP Journal of Organizational Behavior, XI, 7-22.

Mohd Adnan, S. N. S., \& Valliappan, R. (2019). Communicating shared vision and leadership styles towards enhancing performance. International Journal of Productivity and Performance Management, 68(6), 1042-1056. https://doi.org/10.1108/IJPPM-05-2018-0183

Motowidlo, S. J., \& Van Scotter, J. R. (1994). Evidence that task performance should be distinguished from contextual performance. Journal of Applied Psychology, 79(4), 475.

Muethel, M., \& Hoegl, M. (2016). Expertise Coordination Over Distance: Shared leadership in Dispersed New Product Delelopment Teams. 8, 327-348. https://doi.org/10.1108/S1479-357120160000008012

Müller, E., Pintor, S., \& Wegge, J. (2018). Shared leadership effectiveness: perceived task complexity as moderator. Team Performance Management, 24(5-6), 298-315. https://doi.org/10.1108/TPM-09-2017-0048

Nassif, A. G. (2018). Human Resource Management Review Heterogeneity and centrality of " dark personality " within teams, shared leadership, and team performance: A conceptual moderated-mediation model. Human Resource Management Review, November. https://doi.org/10.1016/j.hrmr.2018.11.003

Nassif, A. G. (2019). Heterogeneity and centrality of "dark personality" within teams, shared leadership, and team performance: A conceptual moderated-mediation model. Human Resource Management Review, 29(4), 1-14. https://doi.org/10.1016/j.hrmr.2018.11.003

Noorman, M., Akmal, M., Osman, F., \& Ibrahim, Z. (2015). Malaysian Computer Professional : Assessment of Emotional Intelligence and Organizational Commitment. Procedia - Social and Behavioral Sciences, 172, 238245.

Quigley, N. R., Tesluk, P. E., Locke, E. A., \& Bartol, K. M. (2007). A multilevel investigation of the motivational mechanisms underlying knowledge sharing and performance. Organization Science, 18(1), 71-88.

Shafi, M., Zoya, Lei, Z., Song, X., \& Sarker, M. N. I. (2020). The effects of transformational leadership on employee creativity: Moderating role of intrinsic motivation. Asia Pacific Management Review, 1-11. https://doi.org/10.1016/j.apmrv.2019.12.002

Shang, Y., Chong, M. P. M., Xu, J., \& Zhu, X. (2019). Authentic leadership and creativity in China: The role of students' regulatory-focused behaviors and supervisors' power sources. Thinking Skills and Creativity, 34, 1-15. https://doi.org/10.1016/j.tsc.2019.100592

Sung, D., Chang, K., Wook, Y., \& Young, D. (2014). Computers in Human Behavior An analysis of shared leadership , diversity, and team creativity in an e-learning environment. Computer of Human Behaviour. https://doi.org/10.1016/j.chb.2013.10.064

Wu, C., \& Chen, T. (2018). Collective psychological capital: Linking shared leadership, organizational commitment, 
Jurnal Bisnis dan Manajemen

http://jurnal.unmer.ac.id/index.php/jbm
Volume 7 No 2 2020

HIm. 74 - 84

and creativity. International Journal of Hospitality Management, 74(May 2017), 75-84.

Wu, Q., \& Cormican, K. (2016). Shared leadership and team creativity: A social network analysis in engineering design teams. Journal of Technology Management and Innovation, 11(2), 2-12. https://doi.org/ISSN: 0718-2724 